\title{
Wpływ złagodzenia reżimu granicznego na Białorusi na wielkość ruchu turystycznego - wstęp do badań The influence of relaxation of the border regime in Belarus on tourist traffic - introduction to the research
}

\author{
Marek Więckowski • 1 Aliaksandr Cyargeenka \\ Instytut Geografii i Przestrzennego Zagospodarowania im. S. Leszczyckiego PAN \\ ul. Twarda 51/55, 00-818 Warszawa \\ marekw@twarda.pan.pl•aliaksandrc@twarda.pan.pl
}

Zarys treści. W artykule podjęto próbę wypełnienia luki w badaniach zmian reżimu granicy polsko-białoruskiej i ich konsekwencji. Z drugiej strony opracowanie kontynuuje badania dotyczące zmienności granic polskich i ich sąsiadów. W artykule zawarto wyniki analizy zmian uregulowań prawnych, mających wpływ na rozwój zagranicznej turystyki przyjazdowej do Białorusi (takie jak wprowadzenie ruchu bezwizowego oraz stref bezwizowych). Przedstawiono istniejące przejścia graniczne oraz powstawanie nowych, wraz ze specyfiką stref bezwizowych i możliwościami funkcjonowania w nich turystyki. Ukazano także dynamikę natężenia i struktury turystyki przyjazdowej na Białoruś w okresie 2011-2019.

Słowa kluczowe: Polska, Białoruś, granica państwa, ruch graniczny, strefy bezwizowe, reżim graniczny, turystyka.

\section{Wstęp}

Podróże zagranicznych turystów do Białorusi były przez wiele lat bardzo ograniczone. W ostatnich latach nastąpiła jednak znacząca poprawa warunków i możliwości przekraczania granicy oraz podróżowania do Białorusi. Kluczowe znaczenie dla wprowadzania nowych udogodnień mają zmiany reżimu granicznego i łagodzenie przepisów wjazdowych, które regulowane są na szczeblu centralnym.

Granica polsko-białoruska dobrze nadaje się do analizy przemian funkcjonalnych. Specyfika polityki na osi Bruksela-Warszawa-Mińsk przypomina polityczną sinusoidę (Błaszczak, 2017). W okresie ostatnich 20 lat poziom jej przenikalności ulegał kilkakrotnie zmianom na skutek czynników politycznych i ekonomicznych (Komornicki, 2008). W kolejnych ponad dziesięciu latach zmiany te wydają się jeszcze większe, a nowe regulacje prawne wprowadzone w ostatnich czterech latach są wyjątkowe w relacjach polsko-białoruskich. Dzięki dekretom Prezydenta Białorusi powstają zarówno nowe strefy bezwizowe, jak też inne regulacje ułatwiające wjazd cudzoziemcom do Białorusi. Zmiany te są z jednej strony analogiczne do zmian reżimu w innych częściach świata w różnych okresach, a z drugiej są unikatowe, zwłaszcza z powodu specyfiki izolacji Białorusi na arenie międzynarodowej w ostatnich dziesięcioleciach. 
Omawiane zagadnienia dotyczą zewnętrznej granicy Unii Europejskiej i jednocześnie sąsiedztwa kraju, który do niedawna mocno ograniczał międzynarodowe kontakty i możliwości wjazdu obywateli innych państw na swoje terytorium. Poniższy artykuł ma trzy komplementarne cele o charakterze poznawczym. Są nimi:

- analiza zmian uregulowań prawnych mających wpływ na rozwój zagranicznej turystyki przyjazdowej do Białorusi;

- analiza specyfiki stref bezwizowych;

- ukazanie dynamiki natężenia i struktury turystyki przyjazdowej na Białoruś w okresie 2011-2019.

\section{Otwieranie się granic a wychodzenie z izolacjonizmu}

Granice państw odzwierciedlają relacje między sąsiadami - zmieniającą się kombinację konfliktu, konkurencji, podporządkowania i współpracy, a także różne aspekty postrzegania granicy (Kolosov i inni, 2018), tym samym pomagają interpretować napięcia, a także łączyć je z relacjami międzykulturowymi i międzypaństwowymi (Scott, 2018). Obserwacja granic jest tym samym istotnym elementem zrozumienia relacji międzypaństwowych.

Zamknięte granice stanowią bariery przestrzenne dla rozwoju społeczno-gospodarczego, sieci transportowych, osadniczych itp. Często są one wynikiem izolacjonizmu, tj. doktryny izolowania państwa na arenie międzynarodowej. „|zolacjonizm może mieć przyczyny zewnętrzne, np. gdy wobec określonego państwa stosowane jest embargo. Może też wynikać z ideologicznych przesłanek władz państwa, które w otwarciu na świat dostrzega zagrożenia swojej suwerenności" (Kałuski, 2017, s. 106). Dodatkowo istnieją obszary izolowane ze względów militarnych. Dla przepływów ludzi istotnym elementem jest przenikalność, czyli możliwości swobodnego przekraczania granicy przez ludzi oraz swobodnego przewozu przez nią towarów. Możemy wyróżnić granice: nieprzepuszczalne, częściowo przepuszczalne, znacznie przepuszczalne oraz całkowicie przepuszczalne (Ciok, 1990). Granice są realnymi barierami dla ruchu turystycznego. Te zamknięte uniemożliwiają przepływy ludności (izolacja sąsiednich obszarów), a przepuszczalne (otwarte) - stanowią ograniczenia lub filtrują ruch ludności. Stopień przenikalności zależy od funkcji granicy, jak również od stopnia podobieństwa społeczno-kulturowego obydwu stron (Donnan i Wilson, 1999). Podczas rozważań społecznych interakcji niezwykle ważne jest też uwzględnienie kulturalnych i lingwistycznych podobieństw i różnic. Dużo więcej osób jest skłonnych przekroczyć granicę, jeżeli język po drugiej stronie jest tym samym lub zbliżonym do ich własnego (Eriksson, 1979; Leimgruber, 1981; Timothy, 1995). Podobnie przedstawia się problem bezpieczeństwa osobistego. Jeżeli ludzie obawiają się zagrożeń, granica może stać się barierą, gdyż stają się oni niechętni do jej przekraczania (Arreola i Curtis, 1993).

Łagodzenie reżimu może następować w różny sposób. Wprowadzane są coraz mniejsze wymagania w pozyskaniu wizy, możliwości wjazdu bez wizy, otwierane są specjalne przejścia graniczne lub strefy, do których wjazd odbywa się na innych, uproszczonych zasadach. Jednakże rozwiązania odgórne - zmiany przepisów - to dopiero pierwszy krok do wzrostu napływu turystów do danego kraju. To, czy wzrost ten będzie znaczący, czy turyści będą chętnie przyjeżdżać, zależy od wielu czynników. Szczególnie pomiędzy krajami o niesprzyjających relacjach oraz po okresie długiej izolacji znaczącym utrudnieniem po- 
zostaje bariera mentalna. Jest ona trudna do przełamania. Występują również bariery wyobrażeniowe, ponieważ istnieje siła sugestii oraz stereotypy, bojaźń przed przekroczeniem granicy, niepewność i brak informacji dotyczącej tego, co jest po drugiej stronie i możliwości korzystania turystycznego z kraju sąsiada. Granice, nawet po złagodzeniu reżimu i ich otwarciu, pozostawiają trwałe ślady, tworząc efekt bariery mentalnej, która często pogłębiana jest przez niechęć do wzajemnego poznania (Herzog, 1990; Minghi, 1994; Timothy, 2001; Więckowski, 2010). Niezależnie od różnic, jakie występują między sąsiadującymi krajami, istnieje też zwiększony dystans funkcjonalny (Reynolds i McNulty, 1968), który dodatkowo spotęgowany jest przez istnienie wspomnianej bariery mentalnej. Dystans funkcjonalny może być zwiększony przez wrogie nastawienie do sąsiadów. Przekraczanie granic i chęć odwiedzenia kraju sąsiedniego wymaga pokonania dodatkowej odległości, co zmniejsza potencjalną liczbę osób chcących ją pokonać, by przekroczyć granicę (Więckowski, 2010). Dopiero otwieranie się na innych ludzi, chęć ich poznania i zaakceptowania prowadzi do stopniowego wzrostu wyjazdów do sąsiedniego kraju (Więckowski, 2010), a proces poznawania i podróży transgranicznych nazwany został „familiaryzacją” (Bas Spieriengs i Van der Velde, 2008).

Omawiane zagadnienie jest istotne z naukowego punktu widzenia i wpisuje się w koncepcję kierunków badań naukowych dotyczących granic w Europie Środkowej i Wschodniej zaproponowanych przez V. Kolosova i M. Więckowskiego (2018). Dotyczy przede wszystkim aspektów związanych z wpływem granicy na życie codzienne społeczności granicznych oraz z zarządzaniem granicą (Kolosov i Więckowski, 2018).

Mimo zasadniczego znaczenia granic w podróżach międzynarodowych niewielu autorów badało je w kontekście turystyki, a szczególnie w kontekście efektu barier, jakie tworzą. Granice pełnią rolę barier preferencji turystycznych, ograniczając wybór destynacji do obszaru swojego kraju. Wpływa to na występowanie silnej dominacji ruchu krajowego na obszarze przygranicznym. Jest to efektem różnic i podobieństw, uprzedzeń i atrakcyjności. Do nielicznych publikacji dotyczących przejść granicznych oraz ruchu granicznego na zewnętrznych granicach UE należy zaliczyć prace: B. Szejgiec i R. Wiśniewskiego (2008), T. Komornickiego i A. Miszczuka (2010), T. Komornickiego (2010), R. Anisiewicz i T. Palmowskiego (2014), oraz T. Komornickiego i R. Wiśniewskiego (2017). Kwestie dotyczące ruchu turystycznego i mobilności na tle innych granic Polski były przedmiotem badań M. Więckowskiego (2008, 2010).

Warto przypomnieć, że granica polsko-białoruska liczy 418,24 km, co stanowi 13,6\% długości całej granicy lądowej Polski i 10,5\% długości granicy białoruskiej. Powstała po rozpadzie ZSRR, pozostając w tym samym miejscu. Wstąpienie Polski i kilku innych krajów do strefy Schengen w 2007 r. spowodowało, że wschodnie granice Polski, które stały się granicami zewnętrznymi Unii Europejskiej i strefy Schengen - jak w przeszłości granice między ZSRR a innymi krajami - utrudniają stosunki transgraniczne, zwłaszcza w skali lokalnej. Granice te przełamały niedawno utworzone i wciąż stosunkowo słabe ponadnarodowe sieci gospodarcze, społeczne i kulturalne z Ukrainą, Białorusią i Rosją oraz utrudniły współpracę transgraniczną (Komornicki i Miszczuk, 2010; Komornicki, 2010, Jakubowski i inni, 2017; Dołzbłasz, 2017, 2018; Marin, 2017). Przez wiele lat potrzeba uzyskania wizy białoruskiej była znacznym utrudnieniem w przekraczaniu granicy (Marin, 2017). Co prawda w większości obiektów noclegowych, na przykład w Białowieży (zwłaszcza w hotelach), można było otrzymać pomoc w uzyskaniu wizy, jednak czas oczekiwania na wizę, i tak sto- 
sunkowo krótki, bo zaledwie 3-4 dni, uniemożliwia wizyty na Białorusi turystom polskim przybywającym w te rejony na weekend (Więckowski 2010, s. 200).

Nowe uregulowania prawne, powstawanie stref bezwizowych oraz konsekwencji ich wprowadzania nie były jeszcze przedmiotem dogłębnych analiz. Artykuł wypełnia tę lukę badawczą, ale jednocześnie Autorzy mają świadomość, że należy go traktować jako wstęp do dalszych badań. Zagadnienie jest jeszcze nowe i nie ma pełnych danych, aby udowodnić wpływ łagodzenia reżimu granic na wzrost ruchu turystycznego do Białorusi, choć pierwsze wnioski można już zaproponować.

\section{Źródła danych i materiałów do analizy}

W artykule wykorzystano materiały statystyczne uzyskane z kilku źródeł, w tym z: Głównego Urzędu Statystycznego (GUS, Turystyka 2018), Komendy Głównej Straży Granicznej, Departamentu Celnego Ministerstwa Finansów, a także instytucji statystycznych Rosji, Białorusi (Narodowy Komitet Statystyczny Republiki Białorusi - Nacyonalnyj statisticzeskij..., 2019) i Ukrainy. Odniesiono się również do wyników innych analiz i istniejącej literatury przedmiotu. Wiele informacji i danych pochodziło ze źródeł białoruskich, które są w większości przypadków pierwotne, co daje nadzieję na ich oryginalność, niezbędną w analizach. Jak wspomniano we wstępie poniższy artykuł ma trzy komplementarne cele o charakterze poznawczym. Aby uzyskać satysfakcjonujące efekty analiz, w ramach każdego z zagadnień posłużono się szeregiem danych statystycznych oraz dokumentów. Do analizy zmian reżimu granicy, przepisów wizowych itp. wykorzystano: dzienniki ustaw oraz oficjalne portale internetowe Prezydenta Republiki Białorusi (RB) oraz Rady Ministrów RB (Obwieszczenie..., 2015; Oficyalnyj..., 2019; Nacyonalnyj prawowoj..., 2019), Państwowego Komitetu Granicznego (Informacyja..., 2019) oraz inne (Punkty... 2019; Rieżym..., 2019; Ob ustanowlenii..., 2019). Do ukazania specyfiki przejść granicznych i możliwości funkcjonowania turystyki w strefach bezwizowych posłużyły: najnowszy aktualny dekret dotyczący stref bezwizowych (Ob ustanowlenii..., 2019), inne dekrety Prezydenta RB zamieszczone na oficjalnym portalu (Oficyalnyj..., 2019) i Rozporządzenia Rady Ministrów RB (Nacyonalnyj prawowoj..., 2019). Do analizy dynamiki natężenia i struktury turystyki przyjazdowej na Białorusi w okresie 2011-2019, ze szczególnym uwzględnieniem stref bezwizowych, wykorzystano źródła statystyczne (Nacyonalnyj statisticzeskij..., 2019; O razwitii..., 2019, s. 9-12; Turizm..., 2019, s. 30).

\section{Granica polsko-białoruska i umowy polsko-białoruskie zmieniające reżim granicy}

Po upadku ZSRR początkiem budowania relacji polsko-białoruskich było podpisanie 10 października 1991 r. Deklaracji o dobrym sqsiedztwie, wzajemnym zrozumieniu i współpracy. Dokument podkreślał wolę budowania przyjaznych stosunków, opartych między innymi na potwierdzeniu istniejącej granicy państwowej jako czynnika stabilności i pokoju w Europie oraz deklarował wszechstronną współpracę, a także wzajemną pomoc. Ostateczne rozwiązanie Związku Radzieckiego i postępująca transformacja wymusiła konieczność podpisania nowej umowy międzypaństwowej, co nastąpiło 2 marca 1992 r. Podstawowymi, pierwszymi umowami dotyczącymi relacji polsko-białoruskich były: 
- porozumienie między Republiką Białoruś a Rzeczpospolitą Polską o nawiązaniu stosunków dyplomatycznych z 2 marca 1992 r.,

- porozumienie między Rządem Rzeczpospolitej Polskiej a Rządem Republiki Białoruś o głównych zasadach współpracy transgranicznej z 24 kwietnia 1992 r. (Dz. U. 1993, nr 14, poz. 245),

- traktat między Rzeczpospolitą Polską a Republiką Białoruś o dobrym sąsiedztwie i przyjaznej współpracy z 23 czerwca 1992 r. (Dz. U. 1993, nr 118, poz. 527).

Jako podstawy prawne możliwości przekraczania granicy stworzono szereg umów i dokumentów, z których największe znaczenie miały umowy o przejściach granicznych oraz o ruchu osobowym.

W kwestii przekraczania granic stworzono - wspomnianą wcześniej - umowę między Rządem Rzeczypospolitej Polskiej a Rządem Białorusi w sprawie przejść granicznych z 24.041992 r. (weszła w życie 15.10.1992 r. - zmieniona w ramach porozumienia z dnia 2 marca 2005 r. weszła w życie 30 marca 2005 r.). Drugim dokumentem regulującym kwestie przekraczania granic była umowa między Rządem Rzeczypospolitej Polskiej a Rządem Białorusi w sprawie ruchu osobowego z dn. 26.08.2003 r. W 2004 r. Polska wstąpiła do Unii Europejskiej, ale dopiero włączenie jej do strefy Schengen wymusiło znaczące zmiany w reżimie granicznym. Przede wszystkim granica polsko-białoruska stała się zewnętrzną granicą UE oraz strefy Schengen. Do wjazdu na terytorium Polski wymagane były wizy. Wejście Polski do strefy Schengen wymogło tym samym stworzenie nowej umowy o ruchu osobowym pomiędzy Rządem Rzeczypospolitej Polskiej a Rządem Białorusi, którą sporządzono 5 grudnia 2007 r. (weszła w życie 06.08.2008).

Od 2015 r. obserwujemy niespotykaną wcześniej skalę i tempo zmian dotyczących reżimu granicznego. Decyzją Prezydenta Republiki Białoruś weszły w życie liczne dekrety podpisane przez stronę białoruską, wprowadzające strefę bezwizowego ruchu, które mają ułatwić odwiedzającym przekraczanie granicy państwowej. Pierwszym dokumentem, który zapoczątkował proces wprowadzenia stref bezwizowych na Białorusi, był Dekret nr 115 Prezydenta Republiki Białoruś z dnia 9 marca 2015 r., który (od wejścia w życie 12.06.2015 r.) zezwalał na bezwizowy pobyt czasowy do 3 dni w Parku Narodowym Puszcza Białowieska. Kolejne zmiany wprowadzane były na podstawie dekretów Prezydenta Białorusi, a ich celem było rozszerzanie stref bezwizowych oraz wydłużanie okresu pobytu do 5 dni w 2016 r., 10 dni w 2018 oraz do 15 dni w 2019 r. Poza strefami lądowymi wprowadzono specjalną strefę, którą jest lotnisko Mińsk. Pierwsze dekrety (wprowadzone w 2015 r.) zezwalały na bezwizowy pobyt na Białorusi przez okres do 3 dni obywatelom Chińskiej Republiki Ludowej przybywającym przez lotnisko Mińsk. Kolejna zmiana - od 12.02.2017 r. - wydłużyła pobyt do 5 dni na całości terytorium obcokrajowcom z 80 państw. Od 27.07.2018 r. przedłużono okres pobytu do 30 dni. Unikatowym rodzajem ułatwień w przekraczaniu granicy jest reżim bezwizowy wprowadzany podczas imprez sportowych na Białorusi. Po raz pierwszy czasowe otwarcie ruchu bezwizowego miało miejsce od 25 kwietnia do 31 maja 2014 r. podczas Mistrzostwa Świata w Hokeju na Lodzie 2014 w Mińsku. Kolejne otwarcie nastąpiło od 10 maja do 10 lipca, zaś dla turystów z 98 państw od 10 czerwca do 10 lipca 2019 r. podczas II Igrzysk Europejskich w Mińsku (na podstawie biletu papierowego lub elektronicznego oraz dla osób znajdujących się na liście sportowców lub personelu, a także na podstawie posiadania ubezpieczenia oraz pieniędzy). Analogiczny do poprzedniego reżim bezwizowy obowiązywał od 1 do 20 września 2019 r. podczas meczu lekkoatletycznego Europa - USA. W tabeli 1 zestawiono 
Tabela 1. Dekrety Prezydenta Republiki Białorusi dotyczące wprowadzenia reżimów bezwizowych

\begin{tabular}{|c|c|c|c|c|c|c|}
\hline \multicolumn{3}{|c|}{$\begin{array}{l}\text { Dekret Prezydenta Republiki Białorusi } \\
\text { Decree of the President of the Repub- } \\
\text { lic of Belarus }\end{array}$} & \multirow{2}{*}{$\begin{array}{l}\text { Długość pobytu } \\
\text { Length of stay }\end{array}$} & \multirow{2}{*}{$\begin{array}{l}\text { Strefa bezwizowa, } \\
\text { wydarzenie } \\
\text { Visa-free zone, event }\end{array}$} & \multirow{2}{*}{$\begin{array}{l}\text { Zasięg terytorialny } \\
\text { Areal extent }\end{array}$} & \multirow{2}{*}{$\begin{array}{l}\text { Niezbędne dokumenty } \\
\text { i wymagania } \\
\text { Necessary documents and } \\
\text { requirements }\end{array}$} \\
\hline $\begin{array}{l}\mathrm{Nr} \\
\mathrm{No}\end{array}$ & $\begin{array}{l}Z \text { dnia } \\
\text { Dated }\end{array}$ & $\begin{array}{l}\text { Wejście } \\
\text { w życie } \\
\text { Entry into } \\
\quad \text { force }\end{array}$ & & & & \\
\hline \multicolumn{7}{|c|}{ Strefy przygraniczne/Border zones } \\
\hline 115 & 09.03 .2015 & 12.06.2015 & do 3 dób up to 3 days & $\begin{array}{l}\text { Park Narodowy Puszcza } \\
\text { Białowieska } \\
\text { Belovezhskaya Pushcha } \\
\text { National Park }\end{array}$ & $\begin{array}{l}\text { części rejonów: kamienieckiego, } \\
\text { prużańskiego z obwodu brzeskiego } \\
\text { oraz świsłockiego z obwodu grodzień- } \\
\text { skiego parts of the Kamenets and } \\
\text { Pruzhany Districts of Brest Region and } \\
\text { the Svislach District of Hrodna Region }\end{array}$ & $\begin{array}{l}\text { paszport, indywidualny lub gru- } \\
\text { powy dokument potwierdzający } \\
\text { zwiedzenie Parku } \\
\text { passport, individual or group docu- } \\
\text { ment confirming entry into the Park }\end{array}$ \\
\hline 318 & 23.08 .2016 & 26.10 .2016 & do 5 dób up to 5 days & $\begin{array}{l}\text { park turystyczno-rekrea- } \\
\text { cyjny Kanał Augustowski } \\
\text { Augustów Canal tourism } \\
\text { and recreation park }\end{array}$ & $\begin{array}{l}\text { miasto Grodno, sielsowiety: Hoża, } \\
\text { Kopciówka, Odelsk, Padłabienie, } \\
\text { Sopockin z rejonu grodzieńskiego } \\
\text { city of Hrodna, as well as Gozha, } \\
\text { Koptevka, Padlabiennie, Adelsk and } \\
\text { Sapockin areas within Hrodna District }\end{array}$ & $\begin{array}{l}\text { paszport, indywidualny lub gru- } \\
\text { powy dokument, potwierdzający } \\
\text { zwiedzenie Kanału Augustowskiego } \\
\text { passport, individual or group } \\
\text { document confirming visit to the } \\
\text { Augustów Canal }\end{array}$ \\
\hline \multirow[t]{2}{*}{462} & \multirow[t]{2}{*}{26.12 .2017} & \multirow[t]{2}{*}{ 01.01.2018 } & \multirow[t]{2}{*}{ do 10 dób/up to 10 days } & $\begin{array}{l}\text { strefa turystyczno-rekre- } \\
\text { acyjna Brześć } \\
\text { Brest tourism and recre- } \\
\text { ation zone }\end{array}$ & $\begin{array}{l}\text { miasto Brześć, rejony: brzeski, żabi- } \\
\text { necki, kamieniecki, prużański z ob- } \\
\text { wodu brzeskiego oraz rejon świsłocki } \\
\text { z obwodu grodzieńskiego } \\
\text { city of Brest and Districts of Brest, } \\
\text { Zhabinka, Kamenets and Pruzhany } \\
\text { in Brest Region, as well as Svislach } \\
\text { District in Hrodna Region }\end{array}$ & \multirow{2}{*}{$\begin{array}{l}\text { paszport, indywidualny lub gru- } \\
\text { powy dokument, potwierdzający } \\
\text { zwiedzenie strefy turystyczno- } \\
\text {-rekreacyjnej Brześć bądź parku } \\
\text { turystyczno-rekreacyjnego Kanał } \\
\text { Augustowski } \\
\text { passport, individual or group } \\
\text { document confirming visit to Brest } \\
\text { tourism and recreation Zone or } \\
\text { Augustów Canal tourism and } \\
\text { recreation park }\end{array}$} \\
\hline & & & & $\begin{array}{l}\text { park turystyczno-rekrea- } \\
\text { cyjny Kanał Augustowski } \\
\text { Augustów Canal tourism } \\
\text { and recreation park }\end{array}$ & $\begin{array}{l}\text { miasto Grodno oraz rejon grodzieński } \\
\text { city of Hrodna and Hrodna District }\end{array}$ & \\
\hline
\end{tabular}




\begin{tabular}{|c|c|c|c|c|c|c|}
\hline 300 & 07.08 .2019 & 10.11.2019 & do 15 dób/up to 15 days & $\begin{array}{l}\text { przestrzeń Brześć-Grodno } \\
\text { Brest-Hrodna area }\end{array}$ & $\begin{array}{l}\text { miasto Brześć, rejony: brzeski, żabi- } \\
\text { necki, kamieniecki, prużański z obwo- } \\
\text { du brzeskiego oraz m. Grodno, rejony: } \\
\text { grodzieński, brzestowicki, wołkowyski, } \\
\text { werenowski, lidzki, świsłocki i szczu- } \\
\text { czyński z obwodu grodzieńskiego } \\
\text { city of Brest and Districts of Brest, } \\
\text { Zhabinka, Kamenets and Pruzhany } \\
\text { in Brest Region, as well as Hrodna and } \\
\text { the Districts of Hrodna, Byerastavitsa, } \\
\text { Vawkavysk, Voranava, Lida, Svislach } \\
\text { and Shchuchyn in Hrodna Region }\end{array}$ & $\begin{array}{l}\text { paszport, indywidualny lub grupo- } \\
\text { wy dokument potwierdzający zwie- } \\
\text { dzenie przestrzeni Brześć-Grodno } \\
\text { passport, individual or group } \\
\text { document confirming visit to the } \\
\text { Brest-Hrodna area }\end{array}$ \\
\hline \multicolumn{7}{|c|}{ Strefy portu lotniczego/Airport zones } \\
\hline 8 & 09.01.2017 & 12.02 .2017 & $\begin{array}{l}\text { do } 5 \text { dób } \\
\text { up to } 5 \text { days }\end{array}$ & \multirow{2}{*}{$\begin{array}{l}\text { Wjazd i wyjazd przez port } \\
\text { lotniczy Mińsk-2 } \\
\text { arrival and departure via } \\
\text { Minsk-2 airport }\end{array}$} & \multirow{2}{*}{$\begin{array}{l}\text { cała Białoruś } \\
\text { all of Belarus }\end{array}$} & \multirow{2}{*}{$\begin{array}{l}\text { paszport } \\
\text { passport }\end{array}$} \\
\hline 295 & 24.07.2018 & 27.07.2018 & $\begin{array}{l}\text { do } 30 \text { dób } \\
\text { up to } 30 \text { days }\end{array}$ & & & \\
\hline \multicolumn{7}{|c|}{ Okazyjne reżimy bezwizowe/Visa regimes relating to specific occasion or events } \\
\hline 28 & $\begin{array}{l}16.01 .2012 \\
\text { z późniejszymi } \\
\text { zmianami } \\
\text { with subsequent } \\
\text { amendments }\end{array}$ & 23.01.2012 & 25.04.2014-31.05.2014 & $\begin{array}{l}\text { Mistrzostwa Świata w Ho- } \\
\text { keju na Lodzie w Mińsku } \\
\text { Ice Hockey World } \\
\text { Championships }\end{array}$ & \multirow{3}{*}{$\begin{array}{l}\text { cała Białoruś } \\
\text { all of Belarus }\end{array}$} & \multirow{3}{*}{$\begin{array}{l}\text { wjazd i wyjazd przez dowolne } \\
\text { przejście graniczne; dla oficjalnych } \\
\text { uczestników - wpis na oficjalna } \\
\text { listę, zaś dla turystów międzynaro- } \\
\text { dowych - oryginalny lub elektro- } \\
\text { niczny bilet } \\
\text { arrival and departure via a given } \\
\text { border crossing; for official partici- } \\
\text { pants an entry on the official list, or } \\
\text { for international tourists an original } \\
\text { or electronic ticket }\end{array}$} \\
\hline 292 & $\begin{array}{l}24.07 .2018 \\
\text { z późniejszymi } \\
\text { zmianami } \\
\text { with subsequent } \\
\text { amendments }\end{array}$ & 28.07.2018 & 20.05.2019-10.07.2019 & $\begin{array}{l}\text { II Igrzyska Europejskie } \\
\text { w Mińsku } \\
\text { The Second European } \\
\text { Games in Minsk }\end{array}$ & & \\
\hline 308 & 16.08.2019 & 18.08.2019 & 01.09.2019-20.09.2019 & $\begin{array}{l}\text { mecz lekkoatletyczny } \\
\text { Europa-USA } \\
\text { Europe-USA athletics } \\
\text { match }\end{array}$ & & \\
\hline
\end{tabular}

Opracowanie własne na podstawie danych: Oficyalnyj... (2019); Nacyonalnyj statisticzeskij... (2019).

Authors' own elaboration based on data from: Oficyalnyj... (2019), Nacyonalnyj statisticzeskij... (2019). 
wszystkie wprowadzone dekrety wraz z informacjami dotyczącymi dozwolonej długości pobytu, zasięgu terytorialnego oraz dokumentów umożliwiających przekroczenie granicy oraz pobyt na terytorium Białorusi).

Do przekroczenia granicy wymagane są pewne dokumenty i mogą to być: paszport, przepustka, bilet na wydarzenie sportowe (w okresie odbywania się międzynarodowych zawodów sportowych) lub karta migracyjna. Wymagane jest wykupienie ubezpieczenia medycznego, a w razie wyjazdu samochodem - ubezpieczenia komunikacyjnego.

Podsumowując, reżim bezwizowy na Białorusi według kryterium czasu ma charakter: stały (w przygranicznym obszarze i przy wjeździe przez lotniska) oraz czasowy - podczas międzynarodowych wydarzeń sportowych. Według kryterium przestrzennego powstałe strefy bezwizowe na Białorusi można podzielić na:

- przygraniczne strefy bezwizowe (polsko-białoruska i polsko-białorusko-litewska).

- ogólnopaństwową strefę bezwizową - przy wjeździe i wyjeździe przez lotnisko Mińsk lub podczas najważniejszych wydarzeń sportowych.

\section{Kształtowanie się możliwości przekraczania granicy przez przejścia graniczne oraz tworzenie bezwizowych stref}

Zmiany reżimu granicy, wzrost liczby pozwoleń na jej przekraczanie oraz coraz większe możliwości pobytu na Białorusi wymagały również zmian w dostępności i otwartości przejść granicznych. Przejścia graniczne zostały otworzone na podstawie umów zawartych pomiędzy Polską i Białorusią (omówionych we wcześniejszej części artykułu). Przekraczanie granicy polsko-białoruskiej drogą lądową jest możliwe przez 13 przejść, w tym siedem drogowych, pięć kolejowych i jedno rzeczne. Polacy mogą obecnie wjeżdżać na terytorium Białorusi również ze strony innych państw - zwłaszcza Litwy. Dzięki temu wjazd i wyjazd dla obywateli Rzeczypospolitej Polski na Białoruś w trybie bezwizowym jest możliwy przez 15 przejść granicznych, w tym osiem drogowych, dwa kolejowe, dwa rzeczne oraz trzy lotnicze. Dziewięć z 15 przejść jest położonych na lądowej granicy polsko-białoruskiej, kolejne trzy na lądowej granicy litewsko-białoruskiej, a pozostałe trzy znajdują się w portach lotniczych na terytorium Białorusi. Powyższe przejścia, wraz z informacjami na temat dopuszczonego rodzaju ruchu, czasu otwarcia i trybu bezwizowego zostały zestawione w tabeli 2.

Udostępnionymi przejściami granicznymi są również międzynarodowe porty lotnicze w Brześciu i Grodnie. Jednakże jak na razie nie istnieją regularne połączenia z tych lotnisk. Realizowane są jedynie sezonowe loty do Kaliningradu oraz okazyjnie czarterowe do Turcji, Bułgarii i Egiptu. Nie istnieje również żadne połączenie lotnicze Grodna lub Brześcia z Polską. Wynika z tego, iż akcent został położony na rozwój stołecznego lotniska, przygraniczne porty lotnicze zaś pod kątem rozwoju turystyki są przydatne dla zabezpieczenia prywatnych indywidulnych lotów.

Specyficznymi przejściami granicznymi są te, w których jest dozwolony ruch pieszy, a nawet wodny i są nastawione głównie albo jedynie na obsługę turystów. Dwa z funkcjonujących rzecznych przejść granicznych przy granicy polsko-białoruskiej oraz litewsko-białoruskiej obsługują głównie wodny szlak turystyczny prowadzący Kanałem Augustowskim (Rudawka-Lesnaja) i dalej na północ rzeką Niemen w kierunku Litwy (Privałka-Svendubre). 
Po wejściu w życie 10 listopada 2019 r. Dekretu N 300 wszystkie możliwe przejścia na granicy polsko-białoruskiej honorujące ruch osobowy zostały włączone w obsługę białoruskiej przygranicznej strefy bezwizowej. Natomiast pozostałe trzy kolejowe oraz jedno drogowe nie są objęte tym procesem z powodów raczej technicznych, ponieważ ich nadrzędnym celem jest obsługa ruchu towarowego.

Zmiany w reżimie granicy i chęć zaproszenia coraz większej liczby turystów przyczynia się również do przekształcania przestrzennego stref przygranicznych. Od 2015 r. zaczął się proces stopniowego otwierania białoruskiego pogranicza z Polską i częściowo z Litwą na bezwizowy wjazd obcokrajowców. Białoruski obwód brzeski graniczy z województwami lubelskim oraz podlaskim, zaś obwód grodzieński - z województwem podlaskim. Historycznie na pograniczu polsko-białoruskim istniały cztery tak zwane transgraniczne regiony funkcjonalne: Brześć i Biała Podlaska, Puszcza Białowieska, Grodno i Białystok oraz Puszcza Augustowska, które w naturalny sposób są głównymi osiami współpracy oraz kierunkami destynacji turystycznych (Suliga, 1996).

Pierwszą strefą bezwizową został obszar Parku Narodowego Puszcza Białowieska znajdujący się również na terenie Euroregionu Puszcza Białowieska. Kolejna otwarta strefa bezwizowa - park turystyczno-rekreacyjny Kanał Augustowski - powstała na obszarze Euroregionu Niemen, który składał się już z dwóch transgranicznych regionów funkcjonalnych Grodno i Białystok oraz Puszczy Augustowskiej. Proces poszerzenia stref bezwizowych doprowadził finalnie do powstania na Białorusi wzdłuż granicy polsko-białoruskiej i częściowo litewsko-białoruskiej nieprzerwanego pasu bezwizowego, co rzeczywiście ułatwia przemieszczenie się turystów (tab. 3).

Wprowadzenie stref bezwizowych na Białorusi wzdłuż zewnętrznej granicy Unii Europejskiej jest zjawiskiem unikatowym zarówno w przestrzeni, jak i w czasie.

Można pokusić się o pewne porównania z analogicznymi przykładami na świecie:

a) w ujęciu przestrzennym - z małym ruchem granicznym, gdyż dla lokalnych mieszkańców sąsiadujących państw pojawiają się bezwizowe możliwości przekroczenia granicy i poruszania się po obszarach ościennego kraju, znajdujących się bezpośrednio przy granicy oraz z przejściami turystycznymi, które powstały na granicach polsko-słowackiej i polsko-czeskiej;

b) pod kątem warunków - z innymi systemami elektronicznych wiz, jak np. do Kanady, Algierii albo z kubańską Kartą Turysty. Karta ta, podobnie jak w przypadku wjazdu do białoruskich stref bezwizowych, jest również wystawiana głównie przez podmioty turystyczne i zbliżony jest jej koszt. Nowa rosyjska wiza elektroniczna do Obwodu Kaliningradzkiego jest również elementem podobnego systemu uproszczonego przekraczania granic.

\section{Ruch graniczny - mobilność Polaków wyjeżdżających do Białorusi}

Ruch graniczny oraz aspekty związane z liczbą turystów były już przedmiotem kilku badań, analiz i interpretacji. Wcześniejsze badania pokazały znaczną dysproporcję w ruchu granicznym pomiędzy Polską a Białorusią, ukazując wielokrotnie większą liczbę Białorusinów przyjeżdżających do Polski w porównaniu z liczbą Polaków przyjeżdżających na Białoruś (Komornicki, 2008; Komornicki i Miszczuk, 2010; Więckowski, 2008, 2010; Komornicki i Wiśniewski, 2017). 
Tabela 2. Przejścia graniczne z dozwolonym dla obywateli polskich ruchem granicznym na Białoruś i z Białorusi Border crossings at which traffic to and from Belarus involving Polish citizens is permitted

\begin{tabular}{|c|c|c|c|c|c|c|c|}
\hline LP & $\begin{array}{l}\text { Nazwa przejścia } \\
\text { Name of crossing }\end{array}$ & \begin{tabular}{|l|} 
Rodzaj \\
przejścia \\
Type \\
of crossing
\end{tabular} & $\begin{array}{l}\text { Rodzaj ruchu } \\
\text { Type of traffic }\end{array}$ & $\begin{array}{l}\text { Miejscowość graniczna } \\
\text { (Polska, Litwa) } \\
\text { Border localities (Po- } \\
\text { land, Lithuania) }\end{array}$ & $\begin{array}{l}\text { Miejscowość gra- } \\
\text { niczna (Białoruś) } \\
\text { Border localities } \\
\text { (Belarus) }\end{array}$ & $\begin{array}{l}\text { Czas otwarcia } \\
\text { Opening times }\end{array}$ & $\begin{array}{l}\text { Bezwizowy } \\
\text { tryb } \\
\text { Visa-free }\end{array}$ \\
\hline 1. & Kukuryki-Kozłowiczy & $\begin{array}{l}\text { drogowe } \\
\text { road }\end{array}$ & $\begin{array}{l}\text { towarowy } \\
\text { goods }\end{array}$ & Kukuryki (PL) & Kozłowiczy & $\begin{array}{l}\text { całodobowo } \\
24 \text {-hour }\end{array}$ & nie ma/no \\
\hline 2. & Czeremcha-Wysokolitowsk & $\begin{array}{l}\text { kolejowe } \\
\text { rail }\end{array}$ & $\begin{array}{l}\text { towarowy } \\
\text { goods }\end{array}$ & Czeremcha (PL) & Wysokolitowsk & $\begin{array}{l}\text { całodobowo } \\
\text { 24-hour }\end{array}$ & nie ma/no \\
\hline 3. & Siemianówka- Swisłocz & $\begin{array}{l}\text { kolejowe } \\
\text { rail }\end{array}$ & $\begin{array}{l}\text { towarowy } \\
\text { goods }\end{array}$ & Siemianówka (PL) & Swisłocz & $\begin{array}{l}\text { całodobowo } \\
24 \text {-hour }\end{array}$ & nie ma/no \\
\hline 4. & Zubki Białostockie-Bierestowica & $\begin{array}{l}\text { kolejowe } \\
\text { rail }\end{array}$ & $\begin{array}{l}\text { towarowy } \\
\text { goods }\end{array}$ & Zubki (PL) & Bierestowica & $\begin{array}{l}\text { całodobowo } \\
\text { 24-hour }\end{array}$ & nie ma/no \\
\hline 5. & Białowieża-Piererow & $\begin{array}{l}\text { drogowe* } \\
\text { road }\end{array}$ & $\begin{array}{l}\text { osobowy pieszy, rowerowy } \\
\text { passenger on foot or bicycle }\end{array}$ & Białowieża (PL) & Piererow & $\begin{array}{l}\text { od 01.04 do } 30.09 \\
\text { w godz. 8:00-20:00, } \\
\text { a od 1.10 do 31.03 } \\
\text { w godz. 8:00-18:00 }\end{array}$ & $\begin{array}{l}\mathrm{od} / \text { from } \\
12.06 .2015\end{array}$ \\
\hline 6. & Bobrowniki-Bierestowica & $\begin{array}{l}\text { drogowe } \\
\text { road }\end{array}$ & $\begin{array}{l}\text { osobowy, towarowy } \\
\text { passenger and goods }\end{array}$ & Bobrowniki (PL) & Bierestowica & $\begin{array}{l}\text { całodobowo } \\
24 \text {-hour }\end{array}$ & \begin{tabular}{|l} 
od/from \\
10.11 .2019 \\
\end{tabular} \\
\hline 7. & Kuźnica Białostocka-Bruzgi & $\begin{array}{l}\text { drogowe } \\
\text { road }\end{array}$ & $\begin{array}{l}\text { osobowy, towarowy } \\
\text { passenger and goods }\end{array}$ & Kuźnica (PL) & Bruzgi & $\begin{array}{l}\text { całodobowo } \\
24 \text {-hour }\end{array}$ & $\begin{array}{l}\text { od/from } \\
26.10 .2016 \\
\end{array}$ \\
\hline 8. & Połowce-Pieszczatka & $\begin{array}{l}\text { drogowe } \\
\text { road }\end{array}$ & $\begin{array}{l}\text { osobowy } \\
\text { passenger }\end{array}$ & Połowce (PL) & Pieszczatka & $\begin{array}{l}\text { całodobowo } \\
\text { 24-hour }\end{array}$ & $\begin{array}{l}\text { od/from } \\
01.01 .2018\end{array}$ \\
\hline 9. & Sławatycze-Domaczewo & $\begin{array}{l}\text { drogowe } \\
\text { road }\end{array}$ & $\begin{array}{l}\text { osobowy, towarowy do } 7,5 \mathrm{t} \mathrm{dmc} \\
\text { passenger and goods up to } 7.5 \text { tonnes }\end{array}$ & Sławatycze (PL) & Domaczewo & $\begin{array}{l}\text { całodobowo } \\
24 \text {-hour }\end{array}$ & $\begin{array}{l}\text { od/from } \\
01.01 .2018\end{array}$ \\
\hline 10. & Terespol-Brześć & $\begin{array}{l}\text { drogowe } \\
\text { road }\end{array}$ & $\begin{array}{l}\text { osobowy, towarowy do } 3,5 \mathrm{t} \text { dmc } \\
\text { passenger and goods up to } 3.5 \text { tonnes }\end{array}$ & Terespol (PL) & Brześć & $\begin{array}{l}\text { całodobowo } \\
24 \text {-hour }\end{array}$ & $\begin{array}{l}\text { od/from } \\
01.01 .2018 \\
\end{array}$ \\
\hline 11. & Kuźnica Białostocka-Grodno & $\begin{array}{l}\text { kolejowe } \\
\text { rail }\end{array}$ & $\begin{array}{l}\text { osobowy, towarowy } \\
\text { passenger and goods }\end{array}$ & Kuźnica (PL) & Grodno & $\begin{array}{l}\text { całodobowo } \\
\text { 24-hour }\end{array}$ & $\begin{array}{l}\text { od/from } \\
01.01 .2018\end{array}$ \\
\hline 12. & Terespol-Brześć & $\begin{array}{l}\text { kolejowe } \\
\text { rail }\end{array}$ & $\begin{array}{l}\text { osobowy, towarowy } \\
\text { passenger and goods }\end{array}$ & Terespol (PL) & Brześć & $\begin{array}{l}\text { całodobowo } \\
24 \text {-hour }\end{array}$ & $\begin{array}{l}\text { od/from } \\
01.01 .2018 \\
\end{array}$ \\
\hline 13. & Rudawka-Lesnaja & $\begin{array}{l}\text { rzeczne* } \\
\text { river* }^{*}\end{array}$ & $\begin{array}{l}\text { osobowy } \\
\text { passenger }\end{array}$ & Rudawka (PL) & Lesnaja & $\begin{array}{l}\text { od } 01.05 \text { do } 01.10 \\
\text { w godz. 7:00-19:00 }\end{array}$ & $\begin{array}{l}\mathrm{od} / \text { from } \\
26.10 .2016\end{array}$ \\
\hline
\end{tabular}




\begin{tabular}{|c|c|c|c|c|c|c|c|}
\hline 14. & Narodowy port lotniczy Mińsk-2 & $\begin{array}{l}\text { lotnicze } \\
\text { air }\end{array}$ & $\begin{array}{l}\text { osobowy, towarowy } \\
\text { passenger and goods }\end{array}$ & - & Mińsk & $\begin{array}{l}\text { całodobowo } \\
\text { 24-hour }\end{array}$ & \begin{tabular}{|l|} 
od/from \\
12.02 .2017 \\
\end{tabular} \\
\hline 15. & Port lotniczy Brześć & $\begin{array}{l}\text { lotnicze } \\
\text { air }\end{array}$ & $\begin{array}{l}\text { osobowy, towarowy } \\
\text { passenger and goods }\end{array}$ & - & Brześć & $\begin{array}{l}\text { na zamówienie } \\
\text { on request }\end{array}$ & $\begin{array}{l}\text { od/from } \\
01.01 .2018\end{array}$ \\
\hline 16. & Port lotniczy Grodno & $\begin{array}{l}\text { lotnicze } \\
\text { air }\end{array}$ & $\begin{array}{l}\text { osobowy, towarowy } \\
\text { passenger and goods }\end{array}$ & - & Grodno & $\begin{array}{l}\text { na zamówienie } \\
\text { on request }\end{array}$ & $\begin{array}{l}\text { od/from } \\
01.01 .2018 \\
\end{array}$ \\
\hline 17. & Bieniakonie-Soleczniki & $\begin{array}{l}\text { drogowe } \\
\text { road }\end{array}$ & $\begin{array}{l}\text { osobowy, towarowy } \\
\text { passenger and goods }\end{array}$ & Soleczniki (LT) & Bieniakonie & $\begin{array}{l}\text { całodobowo } \\
\text { 24-hour }\end{array}$ & $\begin{array}{l}\mathrm{od} / \text { from } \\
10.11 .2019\end{array}$ \\
\hline 18. & Privałka-Rajgardas & $\begin{array}{l}\text { drogowe } \\
\text { road }\end{array}$ & $\begin{array}{l}\text { osobowy, towarowy } \\
\text { passenger and goods }\end{array}$ & Rajgardas (LT) & Privałka & $\begin{array}{l}\text { całodobowo } \\
\text { 24-hour }\end{array}$ & $\begin{array}{l}\mathrm{od} / \text { from } \\
26.10 .2016 \\
\end{array}$ \\
\hline 19. & Privałka-Svendubre & $\begin{array}{l}\text { rzeczne* } \\
\text { river* }\end{array}$ & $\begin{array}{l}\text { osobowy } \\
\text { passenger }\end{array}$ & Svendubre (LT) & Privałka & $\begin{array}{l}\text { od 01.05 do 01.10 } \\
\text { w godz. 7:00-19:00 }\end{array}$ & $\begin{array}{l}\text { od/from } \\
26.10 .2016\end{array}$ \\
\hline
\end{tabular}

*według białoruskiej klasyfikacji uproszczonego ruchu/simplified traffic under BY classification

Opracowanie własne na podstawie: Obwieszczenie... (2015), Oficyalnyj... (2019), Ob ustanowlenii... (2019), Informacyja... (2019), Punkty... (2019), Rieżym... (2019).

Authors' own elaboration based on data from: Obwieszczenie... (2015), Oficyalnyj... (2019), Ob ustanowlenii... (2019), Informacyja... (2019), Punkty... (2019), Rieżym... (2019).

Tabela 3. Usytuowanie przygranicznych stref bezwizowych na Białorusi względem jednostek terytorialnych lub obszarów transgranicznych Locations of visa-free zones in Belarus in relation to units of territorial administration or transboundary areas

\begin{tabular}{|c|c|c|c|c|c|c|c|}
\hline \multicolumn{2}{|c|}{$\begin{array}{l}\text { Transgraniczne obszary } \\
\text { Transboundary areas }\end{array}$} & \multirow{2}{*}{$\begin{array}{l}\text { Województwo } \\
\text { polskie } \\
\text { Polish } \\
\text { voivodship }\end{array}$} & \multirow{2}{*}{$\begin{array}{l}\text { Obwód } \\
\text { białoruski } \\
\text { Regions } \\
\text { in Belarus }\end{array}$} & \multicolumn{4}{|c|}{$\begin{array}{l}\text { Przygraniczne strefy bezwizowe na Białorusi otwarte dla ruchu } \\
\text { Visa-free border zones in Belarus open to traffic }\end{array}$} \\
\hline Euroregion & $\begin{array}{l}\text { Transgraniczny region } \\
\text { funkcjonalny* } \\
\text { Transboundary func- } \\
\text { tional region* }\end{array}$ & & & 12.06 .2015 & 26.10.2016 & 01.01 .2018 & 10.11.2019 \\
\hline Bug & Brześć i Biała Podlaska & lubelskie & \multirow[b]{2}{*}{ brzeski } & & & \multirow{2}{*}{$\begin{array}{l}\text { strefa turystyczno-rekre- } \\
\text { acyjna Brześć } \\
\text { Brest tourism and recre- } \\
\text { ation zone }\end{array}$} & \multirow{4}{*}{$\begin{array}{l}\text { przestrzeń bezwizowa } \\
\text { Brześć - Grodno } \\
\text { Brest-Hrodna visa-free } \\
\text { area }\end{array}$} \\
\hline $\begin{array}{l}\text { Puszcza } \\
\text { Białowieska }\end{array}$ & Puszcza Białowieska & \multirow{3}{*}{ podlaskie } & & \multicolumn{2}{|c|}{$\begin{array}{l}\text { Park Narodowy Puszcza Białowieska } \\
\text { Belovezhskaya Pushcha National Park }\end{array}$} & & \\
\hline \multirow{2}{*}{ Niemen } & Grodno i Białystok & & \multirow{2}{*}{ grodzieński } & & \multirow{2}{*}{\multicolumn{2}{|c|}{$\begin{array}{l}\text { park turystyczno-rekreacyjny Kanał Augustowski } \\
\text { Augustów Canal tourism and recreation park }\end{array}$}} & \\
\hline & Puszcza Augustowska & & & & & & \\
\hline
\end{tabular}

*według: Suliga (1996, s. 91-92)

Opracowanie własne / Authors’own elaboration. 
W 2017 r. łączna liczba Polaków, którzy przekroczyli wschodnie granice Polski, to 2272,2 tys. osób, w tym granice ukraińską - 1071,5 tys., rosyjską - 691,5 tys. i białoruską - 509,2 tys. Ogromną dysproporcję wykazuje wielkość ruchu w drugą stronę. Liczba cudzoziemców wjeżdżających przez te granice do Polski to 15,77 mln osób, z czego z Białorusi ponad 4 miliony (Turystyka..., 2018).

Według białoruskich danych statystycznych w 2018 r. ogółem 100 tys. obcokrajowców skorzystało z bezwizowego reżimu przekraczania granicy, wśród których prawie 39 tys. turystów i odwiedzających jednodniowych stanowili goście z Polski, niemal 55 tys. - z Litwy oraz ponad 3 tys. - z Łotwy (tab. 4). Liczba turystów (czyli osób spędzających na Białorusi minimum jedną noc) z Polski wynosiła ponad 14 tys., z Litwy -4 tys., zaś z Łotwy -2 tys. Procentowo więcej Litwinów (93\%) niż Polaków (62\%) przekraczało granice jako odwiedzający jednodniowi, a celem ich wyjazdów było dokonanie zakupów (głównie paliw oraz wyrobów alkoholowych lub tytoniowych) w obszarach przygranicznych (oczywiście korzystając z trybu bezwizowego).

Tabela 4. Liczba zorganizowanych turystów zagranicznych i odwiedzających jednodniowych, którzy zwiedzili Białoruś w 2018 r. według stałego miejsca zamieszkania

Numbers of foreign tourists on organised visits and single-day visitors visiting Belarus in 2018 by permanent place of residence

\begin{tabular}{|c|c|c|c|c|}
\hline \multirow[b]{2}{*}{$\begin{array}{l}\text { Państwo } \\
\text { State }\end{array}$} & \multicolumn{2}{|c|}{$\begin{array}{l}\text { Z wizą i bez wizy } \\
\text { With visa and visa free }\end{array}$} & \multicolumn{2}{|c|}{$\begin{array}{l}\text { Bez wizy } \\
\text { Visa free }\end{array}$} \\
\hline & $\begin{array}{l}\text { turyści i odwiedzający } \\
\text { jednodniowi } \\
\text { tourists and others } \\
\text { one-day visits }\end{array}$ & $\begin{array}{l}\text { turyści } \\
\text { tourists }\end{array}$ & $\begin{array}{l}\text { turyści i odwiedzający } \\
\text { jednodniowi } \\
\text { tourists and others } \\
\text { one-day visits }\end{array}$ & $\begin{array}{l}\text { turyści } \\
\text { tourists }\end{array}$ \\
\hline Polska & 46305 & 21332 & 38872 & 14643 \\
\hline Litwa & 59564 & 7387 & 54805 & 3901 \\
\hline Łotwa & 11026 & 7543 & 3165 & 1954 \\
\hline Estonia & 2562 & 2055 & 311 & 155 \\
\hline Niemcy & 3566 & 2562 & 884 & 410 \\
\hline Wielka Brytania & 2298 & 1160 & 307 & 264 \\
\hline Hiszpania & 3175 & 3024 & 93 & 63 \\
\hline Holandia & 1003 & 600 & 189 & 103 \\
\hline Włochy & 749 & 583 & 156 & 105 \\
\hline Francja & 611 & 467 & 150 & 89 \\
\hline Belgia & 1123 & 250 & 95 & 59 \\
\hline Czechy & 524 & 400 & 149 & 27 \\
\hline Chiny & 3277 & 2582 & 154 & 44 \\
\hline Federacja Rosyjska* & 207416 & 99928 & 0 & 0 \\
\hline Inne & 22335 & 17205 & 672 & 347 \\
\hline Razem & 365534 & 167078 & 100002 & 22164 \\
\hline
\end{tabular}

*Obywatele Federacji Rosyjskiej nie są liczeni jako turyści, którzy skorzystali z bezwizowego trybu przekraczania granicy, ponieważ zawsze mieli możliwość bezwizowego wjazdu do Białorusi.

Opracowanie własne na podstawie danych: O razwitii... (2019), s. 9-12; Turizm... (2019, s. 30).

Authors own elaboration based on data from: O razwitii... (2019), p. 9-12; Turizm... (2019, s. 30). 
Łagodzenie reżimu granicznego wpływa na wzrost ruchu turystycznego. Wskazuje na to również analiza według regionów (ryc. 1). Zmiany są ściśle związane z ciągłym procesem wprowadzania trybu bezwizowego w przygranicznych obwodach oraz poprzez stołeczne lotnisko. Największy wzrost liczby turystów (ponad ośmiokrotny w porównaniu do 2016 r.) miał miejsce w obwodzie grodzieńskim w 2017 r. po wprowadzeniu bezwizowego reżimu wjazdu i wyjazdu do parku turystyczno-rekreacyjnego Kanał Augustowski. Po wprowadzeniu bezwizowego reżimu wjazdu i wyjazdu z Parku Narodowego Puszcza Białowieska (obwód grodzieński) również nastąpiło niemal sześciokrotne zwiększenie liczby turystów w 2015 r. w porównaniu z 2014 r. Nawet wprowadzenie okazyjnego reżimu bezwizowego w 2014 r. na okres półtora miesiąca przyczyniło się do zwiększenia liczby turystów przybyłych do miasta Mińsk o 9\% (do 76 tys.) w porównaniu z 2013 r, , a w kolejnym roku - o 37\%. Występuje znaczna dominacja ruchu turystycznego w obwodach brzeskim (26\%) i grodzieńskim (26\%) oraz stołecznym mieście Mińsk (32\%) nad ruchem turystycznym w pozostałych obwodach Białorusi (pozostałe łącznie 16\%).

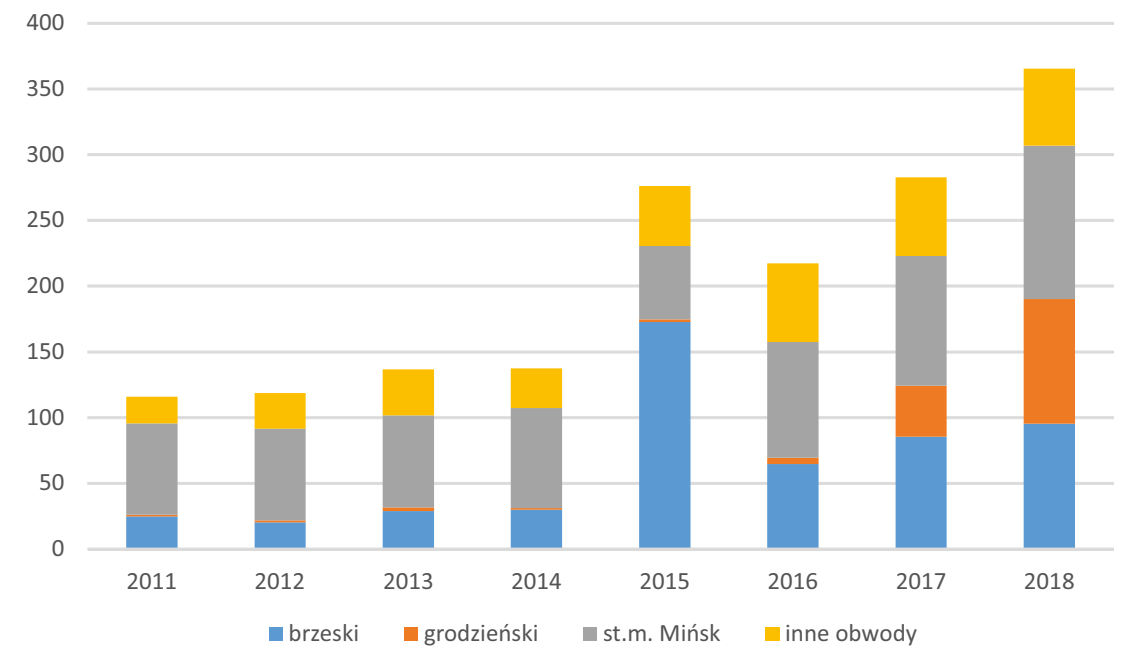

Ryc. 1. Liczba zagranicznych turystów i odwiedzających jednodniowych (w tys.), którzy odwiedzili Białoruś oraz byli obsłużeni przez organizacje turystyczne, według regionów

Numbers (thousands) of foreign tourists on organised visits and single-day visitors visiting Belarus and serviced by tourist organisations, by region

Opracowanie własne na podstawie danych: Turizm... (2018, s. 26); Turizm... (2019, s. 29).

Authors' own elaboration based on data from: Turizm... (2018, s. 26); Turizm... (2019, p. 29).

\section{Zorganizowane wyjazdy turystów do Białorusi}

Od 2015 r. liczba obywateli Polski, którzy skorzystali ze zorganizowanej oferty pobytów na Białorusi, stale rośnie. W 2018 r. liczba ta wyniosła blisko 46 tys. osób, co daje 3 miejsce po Rosjanach (około 207 tys.) i Litwinach (prawie 60 tys.) (tab. 5). Stopniowe wprowadzanie reżimów bezwizowych niewątpliwie przyczyniło się do zwiększenia liczby turystów zarówno z Polski (prawie 27 razy w latach 2014-2018), jak też z innych państw sąsiadujących z Białorusią i należących do Unii Europejskiej - z Litwy (29 razy) oraz z Łotwy (prawie 
Tabela 5. Liczba zorganizowanych turystów zagranicznych oraz odwiedzających jednodniowych, którzy odwiedzili Białoruś w latach 2011-2018, według stałego miejsca zamieszkania Number of foreign tourists on organised visits and single-day visitors visiting Belarus in the years 2011-2018, by permanent place of residence

\begin{tabular}{|l|r|r|r|r|r|r|r|r|}
\hline \multicolumn{1}{|c|}{ Państwo/State } & \multicolumn{1}{c|}{2011} & \multicolumn{1}{c|}{2012} & \multicolumn{1}{c|}{2013} & \multicolumn{1}{c|}{2014} & \multicolumn{1}{c|}{2015} & 2016 & \multicolumn{1}{c|}{2017} & 2018 \\
\hline Polska & 2983 & 2027 & 3126 & 1702 & 5927 & 7992 & 22686 & 46305 \\
\hline Federacja Rosyjska & 83843 & 94187 & 111286 & 113180 & 243908 & 171100 & 191520 & 207416 \\
\hline Litwa & 3170 & 1688 & 2093 & 2023 & 1722 & 5846 & 26182 & 59564 \\
\hline Łotwa & 1550 & 1107 & 1031 & 2348 & 2337 & 2967 & 6533 & 11026 \\
\hline Estonia & 464 & 738 & 670 & 566 & 803 & 1399 & 2769 & 2562 \\
\hline Ukraina & 1693 & 1441 & 1979 & 1776 & 7046 & 5224 & 4363 & 4016 \\
\hline Niemcy & 2191 & 2071 & 1931 & 1704 & 1635 & 2506 & 3102 & 3566 \\
\hline Wielka Brytania & 2412 & 3033 & 1657 & 907 & 773 & 1269 & 2001 & 2298 \\
\hline Hiszpania & 349 & 366 & 160 & 142 & 229 & 489 & 1356 & 3175 \\
\hline Turcja & 3596 & 2768 & 1988 & 962 & 597 & 1075 & 1155 & 1613 \\
\hline Chiny & 364 & 314 & 682 & 266 & 992 & 1579 & 3151 & 3277 \\
\hline Inne & 13434 & 9009 & 10218 & 11868 & 10291 & 15952 & 17876 & 20716 \\
\hline Razem & 116049 & 118749 & 136821 & 137444 & 276260 & 217398 & 282694 & 365534 \\
\hline
\end{tabular}

Opracowanie własne na podstawie danych: Turizm... (2018, s. 27); Turizm... (2019, s. 30)

Authors' own elaboration based on data from: Turizm... (2018, s. 27); Turizm... (2019, s. 30).

5 razy). Wśród państw, które bezpośrednio nie graniczą z Białorusią, największą dynamikę liczby turystów wykazuje Hiszpania - prawie dwudziestokrotny wzrost. Białoruski zagraniczny rynek turystyczny jest obecnie zdominowany przez turystów z Federacji Rosyjskiej, których udział w okresie szczytowym w latach 2013-2015 wynosił ponad 80\%. Natomiast przez ostatnie kilka lat, po wprowadzeniu reżimu bezwizowego, notowano znaczny spadek udziału turystów rosyjskich - do 57\% w 2018 r., lecz w wartościach bezwzględnych liczba turystów z Federacji Rosyjskiej nadal rośnie. Procentowy udział obywateli Polski ciągle rośnie - w 2011 r. stanowili oni około 2,6\% zorganizowanych turystów zagranicznych (podczas największego spadku w 2014 r. - 1,2\%), a w 2018 r. już ponad 12\%.

Porównując liczbę turystów zagranicznych z Polski z liczbą turystów z innych państw spoza Wspólnoty Niepodległych Państw można stwierdzić, że ich udział znacząco rośnie. W 2011 r. procentowy udział turystów z Polski wynosił prawie 10\% i był zbliżony do udziału turystów z Turcji (12\%), Litwy (ponad 10\%), Wielkiej Brytanii (8\%), Niemiec (ponad 7\%) oraz Łotwy (5\%) (ryc. 2). Natomiast w 2018 r. procentowy udział turystów z państw sąsiadujących z Białorusią - z Polski, Litwy oraz Łotwy - powiększył się do odpowiednio: 30\%, 39\% i 7\% (ryc. 3), zaś z grona byłych liderów listy zmniejszył się udział turystów z Turcji - do 1\%, z Niemiec - do 2\%, z Wielkiej Brytanii - do 1,5\%. W tym przypadku, przy otwarciu stref bezwizowych, widoczna jest generalna zależność dynamiki ruchu turystycznego od położenia geograficznego, ponieważ najbardziej z łagodzenia reżimu przekraczania granic skorzystali turyści z państw ościennych: Litwy, Polski oraz Łotwy. 


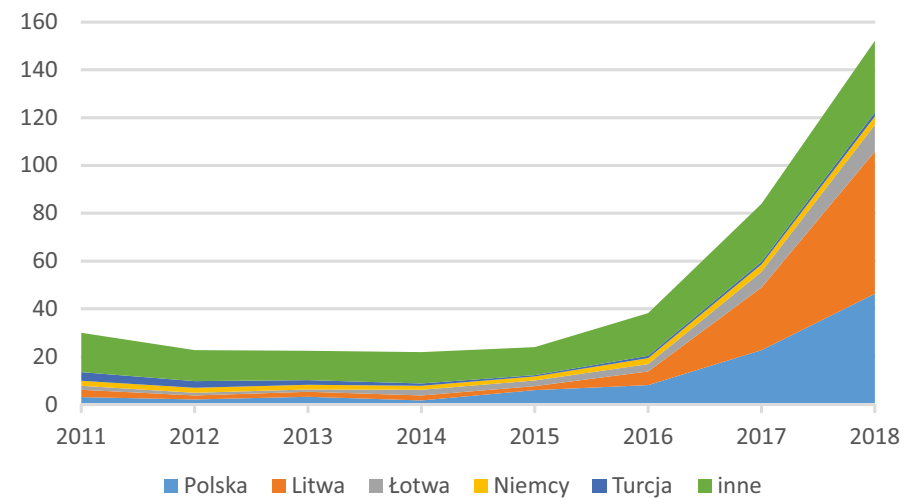

Ryc. 2. Liczba zorganizowanych turystów zagranicznych i odwiedzających jednodniowych (w tys.) z poza Wspólnoty Państw Niepodległych w latach 2011-2018, którzy odwiedzili Białoruś, według stałego miejsca zamieszkania

Numbers (thousands) of foreign tourists on organised visits and single-day visitors visiting Belarus from beyond the Commonwealth of Independent States in the years 2011-2018, by permanent place of residence Opracowanie własne na podstawie danych: Turizm... (2018, s. 27); Turizm... (2019, s. 30).

Authors' own elaboration based on data from: Turizm... (2018, s. 27); Turizm... (2019, s. 30).

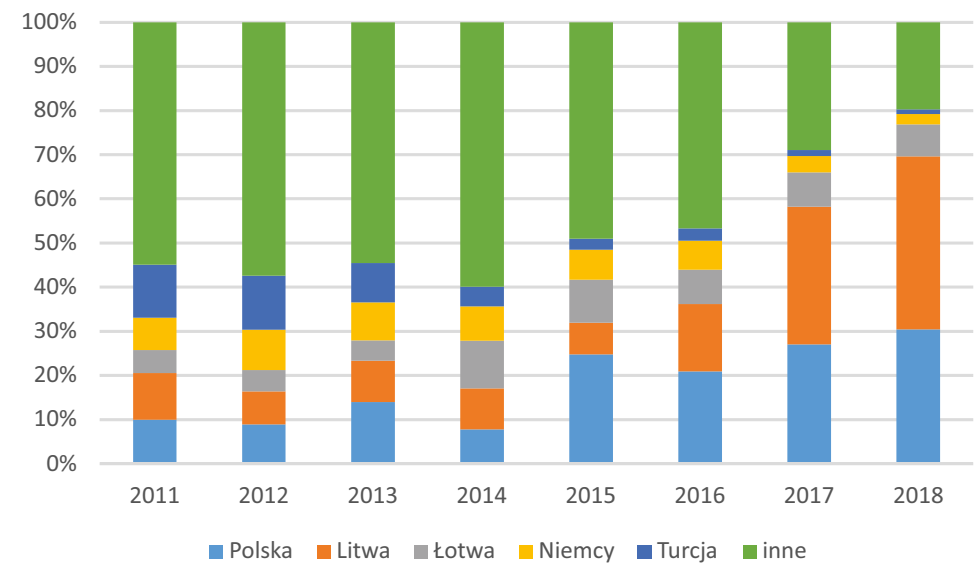

Ryc. 3. Procentowy udział zorganizowanych turystów zagranicznych i odwiedzających jednodniowych z poza Wspólnoty Państw Niepodległych w latach 2011-2018, które odwiedzili Białoruś, według stałego miejsca zamieszkania

Opracowanie własne na podstawie danych: Turizm... (2018, s. 27); Turizm... (2019, s. 30).

Authors' own elaboration based on data from: Turizm... (2018, s. 27); Turizm... (2019, s. 30).

\section{Dyskusja i podsumowanie}

Przeprowadzone badania są z jednej strony próbą wypełnienia luki w badaniach zmian reżimu granicy polsko-białoruskiej i ich konsekwencji, a z drugiej strony w pewien sposób kontynuują opracowania dotyczące zmienności granic polskich i ich sąsiadów. Ukazują pewne nowe procesy, takie jak wprowadzenie ruchu bezwizowego oraz stref bezwizo- 
wych, a także ich wpływ na wzrost ruchu turystycznego do Białorusi. Wprowadzenie przez państwowe władze reżimów oraz stref bezwizowych przez ostatnie 5 lat niewątpliwie wielokrotnie dynamizowało ruch polskich turystów do Białorusi.

Po analizie dokumentów koniecznych do bezwizowego przekraczania granicy możemy stwierdzić, iż w porównaniu z otrzymaniem białoruskiej wizy skorzystanie z reżimu bezwizowego jest łatwiejsze - tańsze, mniej czasochłonne oraz mniej skomplikowane. Do uzyskania wizy potrzebne jest przede wszystkim więcej czasu - co najmniej 2 dni robocze w trybie ekspresowym oraz 6 dni w normalnym, a także opłata. Jednakże należy mieć świadomość, że istnieją też wymogi dotyczące ruchu bezwizowego, których jest kilka zazwyczaj od 5 do 6 i należy też ponieść niewielkie koszty (np. opłaty za ubezpieczenie, czasami konieczne jest wykupienie dodatkowych usług turystycznych).

Z prawnego punktu widzenia wszystkie reżimy bezwizowe na Białorusi były wprowadzone na mocy dekretów („ukazów”) Prezydenta, które są równorzędne z ustawami przyjętymi przez parlament.

Analizy statystyczne wykazały kilka tendencji. Po pierwsze, po wejściu w życie dekretów, a tym samym reżimu bezwizowego na wszystkich przejściach granicznych, znacznie zwiększa się liczbowo intensywność ruchu Polaków. Po drugie, zarówno liczba, jak i udział polskich turystów wjeżdżających do Białorusi od 2015 r. stale rośnie, co związane jest z rozpoczęciem wprowadzania stref bezwizowych. Po trzecie, w kolejnych latach liczba podróżujących nie rośnie gwałtownie, czasami nawet się zmniejsza. Po czwarte, istnieje wyraźny efekt sezonowości w wahaniach liczby Polaków podróżujących na Białoruś z letnim okresem szczytowym.

Porównując z innymi państwami graniczącymi z Polską należy niestety stwierdzić, iż Białoruś jako docelowy kierunek podróży ma nadal dla Polaków niewielkie znaczenie. W 2018 r. Białoruś była na ostatnim miejscu (1\%) według procentowego udziału zagranicznych podróży jednodniowych mieszkańców Polski w wieku 15 lat lub więcej do krajów sąsiadujących z Polską (Turystyka w 2018 roku, 2019, s. 107). Wielkość ruchu granicznego mieszkańców Polski na granicy polsko-białoruskiej (z Polski i do Polski) również plasuje Białoruś na ostatnim miejscu z 1 mln przekroczeń w obie strony w 2018 r. (ok. 500 tys. podróży na Białoruś; dla porównania liczba przekroczeń granicy z Niemcami w 2018 r. wyniosła 45 mln) (Turystyka w 2018 roku, 2019, s. 124). To wszystko wskazuje, że bezwizowy tryb przyczynił się do wzrostu ruchu turystycznego, niemniej jednak ten kierunek nadal jest w inicjalnej fazie w porównaniu z destynacjami wewnątrz Unii Europejskiej.

W ujęciu turystyki transgranicznej i tworzenia się transgranicznej przestrzeni turystycznej relacje polsko-białoruskie są również w inicjalnej fazie. Otwarcie przejść granicznych przeznaczonych do ruchu turystycznego to dopiero początkowa faza według zaproponowanej przez M. Więckowskiego $(2010,2018)$ kształtowania się transgranicznej przestrzeni turystycznej. Jest to faza przestrzeni połączonej (Więckowski, 2010, 2018), a dodatkowo w kilku przypadkach ma charakter przestrzeni sezonowej. Strefy bezwizowe niewątpliwie pomogą w procesie rozwoju przestrzeni transgranicznej i przyczynią się do wzrostu ruchu turystycznego, jednakże ich otwarcie jeszcze nie w pełni odpowiada na potrzeby turystów. Dzięki istnieniu przejścia granicznego istnieje możliwość legalnego przekroczenia granicy i korzystania z obszaru znajdującego się w państwie sąsiednim. Otwierane nowych przejść granicznych po długim okresie zamkniętych granic było typową sytuacja na początku lat 90. XX wieku, kiedy uruchamiano pojedyncze przejścia graniczne (np. Chochołów-Sucha Hora, otwierające obszar Tatr po dwóch stronach granicy) (Więckowski, 2010, s. 181). Otwieranie się Białorusi na turystów zagranicznych może przynieść bardzo pozytywne efekty. Funkcjonalnie i prze- 
strzennie przypomina to strefy turystyczne, jakie powstawały na pograniczu polsko-słowackim (czechosłowackim) (por. Więckowski, 2004, 2010; Lewkowicz i Potocki, 2009) oraz tworzenie przejść turystycznych na granicy polsko-słowackiej i polsko-czeskiej (Więckowski, 2004; Potocki, 2009). Z kolei ruch bezwizowy jest bardzo zbliżony do nowego rozwiązania, jakie w 2019 r. wprowadziła Rosja dla Polaków (i obywateli innych narodowości) chcących wjechać do Obwodu Kaliningradzkiego (a także do regionu Sankt Petersburga) - e-wizy.

Reasumując, łącząc podejście czasowo-przestrzenne możemy stwierdzić, iż na Białorusi przez ostatnie kilka lat powstały trzy rodzaje stref (reżimów) bezwizowych:

- strefy przygraniczne - pogranicze białorusko-polskie oraz częściowo białorusko-litewskie;

- strefy na lotniskach - zwłaszcza w stołecznym porcie lotniczym Mińsk-2 ale również na lotniskach i dworcach kolejowych w Brześciu i Grodnie;

- okazyjne reżimy bezwizowe podczas wydarzeń sportowych.

Dla tych stref (reżimów) można też wskazać podstawowe przyczyny powstania. Strefy wzdłuż zachodniej granicy powstały, aby rozwijać turystykę w obwodach brzeskim i grodzieńskim; na lotnisku stołecznym - żeby rozwijać zarówno port lotniczy oraz znajdujący się koło niego park przemysłowy, jak i stołeczną oraz regionalną turystykę; okazyjne reżimy podczas wydarzeń sportowych powstały, aby promować wizerunek państwa.

Na zakończenie można stwierdzić, że warunki polityczne i instytucjonalne odgrywają decydującą rolę w stosunkach transgranicznych. Kształtują one podstawy prawne i decydują o możliwościach i uwarunkowaniach przekraczania granicy. Ponieważ granice odzwierciedlają relacje między sąsiadami - zmieniającą się kombinację konfliktu, konkurencji, podporządkowania i współpracy, a także różne aspekty postrzegania granicy (Kolosov i inni, 2018) - możemy stwierdzić, że ostatni okres charakteryzuje się otwieraniem się granic i rosnącym zainteresowaniem Białorusią ze strony Polaków i innych obywateli krajów Unii Europejskiej. Na podstawie analizy istniejącej literatury (która w porównaniu z innymi granicami Polski jest jedną z najuboższych) oraz przeprowadzonych badań można stwierdzić, że istnieje dalsza potrzeba prowadzenia i pogłębiania badań naukowych dotyczących granicy, pogranicza i relacji polsko-białoruskich w zmieniających się uwarunkowaniach. Jako podstawowe tematy dalszych badań pogranicza polsko-białoruskiego warto wymienić przede wszystkim: przejścia graniczne, specyfikę ruchu turystycznego, geopolityczne i społeczne zbliżanie się Polski i Białorusi, turystykę handlową, kształtowanie się transgranicznej przestrzeni turystycznej i tworzenie regionów turystycznych, promocję i marketing. Istotne będą również badania dotyczące wyznaczania dalszych kierunków działań, współpracy, ogólnego rozwoju społeczno-gospodarczego i planowania przestrzennego.

Artykuł zawiera wyniki badań przeprowadzonych w ramach projektu badawczego finansowanego przez Narodowe Centrum Nauki, nr 2018/29/B/HS4/02417.

\section{Piśmiennictwo}

Anisiewicz R., Palmowski T., 2014, Small border traffic and cross-border tourism between Poland and the Kaliningrad Oblast of the Russian Federation, Quaestiones Geographicae 2, s. 79-86.

Arreola D.D., Curtis J.R., 1993, The Mexican Border Cities: Landscape anatomy and place personality, University of Arizona Press, Tuscon. 
Błaszczak D., 2017, Pogranicze w sieciach relacji Polski i Białorusi. Teraźniejszość perspektywy rozwoju, [w:] Z. Kurcz (red.), Polskie pogranicza w procesie przemian, 4, Acta Universitatis Wratislavensis, 3776, s. 167-184.

Ciok S., 1990, Problematyka obszarów przygranicznych Polski Południowo-Zachodniej. Studium spoteczno-ekonomiczne, Acta Universitatis Wratislaviensis, 1155, Studia Geograficzne, 68, PWN, Warszawa - Wrocław.

Dołzbłasz S., 2017, Sieci współpracy transgranicznej na pograniczach Polski, Rozprawy Naukowe IGiRR, 40, Uniwersytet Wrocławski.

Dołzbłasz S., 2018, A network approach to transborder cooperation studies as exemplified by Poland's eastern border, Geographia Polonica, 91, 1, s. 63-76.

Donnan H., Wilson T.M., 1999, Borders: frontiers of identity, Nation and State, Oxford, Berg.

Eriksson G.A., 1979, Tourism at the Finish-Swedish-Norwegian borders, [w:] G. Gruber, H. Lamping, W. Lutz, J. Matznetter, K. Vorlaufer (red.), Tourism and borders, Proceedings of the Meeting of the IGU Working Group - Geography of Tourism, s. 88-104.

Herzog L.A., 1990, Where North meets South: cities, space, and politics on the US-Mexico border, Center for Mexican America Studies, University of Texas, Austin.

Informacyja o punktach propuska, 2019, Gosudarstwiennyj pogranicznyj komitiet Riespubliki Biełarus, https://www.gpk.gov.by/situation-at-the-border/punkty-propuska/(18.10.2019).

Jakubowski A., Miszczuk A., Kawałko B., Komornicki T., Szul R., 2017, New borderland. Cross-border relations and regional development, Series: Regions and Cities, Regional Studies Association, Routledge, Oxon - New York.

Kałuski S., 2017, Blizny historii. Geografia granic politycznych współczesnego świata, Wydawnictwo Akademickie Dialog, Warszawa.

Kolosov V., Medvedev A., Zotova M., 2018, Comparing the development of border regions with the use of GIS (the case of Russia), Geographia Polonica, 91, 1, s. 47-61.

Kolosov V., Więckowski M., 2018, Border changes in Central and Eastern Europe: An introduction, Geographia Polonica, 91, 1, s. 5-16.

Komornicki T., 2008, Granica polsko-białoruska jako bariera przestrzenna, [w:] D. Świątek, M. Bednarek, P. Siłka (red.), Współczesne problemy badawcze geografii polskiej-geografia człowieka, Dokumentacja Geograficzna, 2008, 36, s. 55-61.

Komornicki T., 2010, Flows of persons and goods across the Polish segment of the outer boundary of the European Union - results of a research project, EUROPA XXI, 20, s. 9-29.

Komornicki T., Miszczuk A., 2010, Eastern Poland as the borderland of the European Union. Quaestiones Geographicae, 29, 2, s. 55-69.

Komornicki T., Wiśniewski R., 2017, Border traffic as a measure of trans-border relations, Transport Geography, Mitteilungen der Österreichischen Geographischen Gesellschaft, 159, Wien, s. 151-172.

Leimgruber W., 1981, Political boundaries as a factor in regional integration: Examples from Basle and Ticino, Regio Basiliensis, 22, s. 192-201.

Marin A., 2017, Of barriers, breaches and bridges; Cross-border ecotourism and the prospect of horizontal governance acting as a bridge in Belarus-EU Neighbourhood relations, [w:] I. Liikanen, J.W. Scott, T. Sotkasiira (red.), The EU's Eastern Neighbourhood. Migration, borders and regional stability, Routledge, s. 115-133.

Minghi J.V., 1994, European borderlands: International harmony, landscape change and new conflict, [w:] C. Grundy-Warr (red.), World Boundaries, 3, Eurasia, London, Routledge, s. 89-98.

Nacyonalnyj prawowoj Intierniet-portał Riespubliki Biełarus, 2019, http://pravo.by/ (14.10.2019). 
Nacyonalnyj statisticzeskij komitiet Riespubliki Biełarus, 2019, http://www.belstat.gov.by/ (14.10.2019).

Ob ustanowlenii biezwizowogo poriadka wjezda i wyjezda inostrannych grażdan, Ukaz № 300 ot 7 awgusta 2019, 2019, http://president.gov.by/ru/official_documents_ru/view/ukaz-300-ot-7avgusta-2019-g-21740/ (14.10.2019).

Obwieszczenie Ministra Spraw Wewnętrznych z dnia 3 lipca 2015 r. w sprawie ogłoszenia przejść granicznych, rodzaju ruchu dozwolonego przez te przejścia oraz czasu ich otwarcia, 2015, http:// prawo.sejm.gov.pl/isap.nsf/DocDetails.xsp? id=WMP20150000636 (14.10.2019).

Oficyalnyj Intierniet-portał Priezidienta Riespubliki Biełarus, 2019, http://president.gov.by/ (14.10.2019).

O razwitii turizma, diejatielnosti turisticzeskich organizacyj, kołlektiwnych sriedstw razmieszczenija Riespubliki Biełarus za 2018 god, 2019, Nacyonalnyj statisticzeskij komitiet Riespubliki Biełarus, Minsk.

Punkty tamożennogo oformlenija Briestskoj tamożni, 2019, http://www.brest.customs.gov.by/ru/ brest-punkttam_oform-ru/(14.10.2019).

Reynolds D.R., McNutty M., 1968, On the analysis of political boundaries as barriers: a perceptual approach, East Lakes Geographetr, 4.

Rieżym raboty Grodnienskoj riegionalnoj tamożni, 2019, http://www.grt.customs.gov.by/ru/ grt-rabota-ru/(14.10.2019).

Scott J., 2018, Border politics in Central Europe: Hungary and the role of national scale and nation-building, Geographia Polonica, 91, 1, s. 17-32.

Spierings B., van der Velde M., 2008, Shopping, borders and unfamiliarity: consumer mobility in Europe, Tijdschrift voor Economische en Sociale Geografie, 99, 4, s. 497-505.

Suliga J., 1996, Polsko-białoruska współpraca przygraniczna $w$ dziedzinie planowania przestrzennego, [w:] A. Miszczuk, R. Wiśniewski (red.), Informacyjno-infrastrukturalne uwarunkowania współpracy transgranicznej, Norbertinum, 2, s. 91-92.

Szejgiec B., Wiśniewski R., 2008, Struktura i wielkość ruchu granicznego na granicy polsko-ukraińskiej [W:] Europa bez granic - nowa jakość przestrzeni, Rozprawy Naukowe IGiRR UWr, 4, s. 121-129.

Timothy D.J., 1995, Political boundaries and tourism: borders as tourist attractions, Tourism Management, 16, 7, s. 525-532.

Timothy D.J., 2001, Tourism and political boundaries, Routledge Advances in Tourism, London and New York.

Turizm i turisticzeskije riesursy w Riespublikie Biełarus, 2018, [w:] I.W. Miedwiediewa (red.), Statisticzeskij sbornik, Nacyonalnyj statisticzeskij komitiet Riespubliki Biełarus, Mińsk.

Turizm i turisticzeskije riesursy w Riespublikie Biełarus, 2019, [w:] I.W. Miedwiediewa (red.), Statisticzeskij sbornik, Nacyonalnyj statisticzeskij komitiet Riespubliki Biełarus, Mińsk.

Turystyka w 2018 roku, 2019, Główny Urząd Statystyczny, Warszawa.

Więckowski M., 2004, Przyrodnicze uwarunkowania kształtowania się polsko-słowackich więzi transgranicznych, Prace Geograficzne, 195, IGiPZ PAN, Warszawa.

Więckowski M., 2008, New international mobility of Poles, Espace, Populations, Societes, 2, s. 261-270.

Więckowski M., 2010, Turystyka na obszarach przygranicznych Polski, Prace Geograficzne, 224, IGiPZ PAN, Warszawa.

Więckowski M., 2018, From periphery and the doubled national trails to the cross-border thematic trails: New cross-border tourism in Poland, [w:] D.K. Müller, M. Więckowski (red.), Tourism in transitions. Recovering decline, managing change, Geographies of Tourism and Global Change, Springer, Cham, s. 173-186. 


\section{Summary}

Belarus was long a country to which visits by foreign tourists were highly restricted. However, recent years have brought a marked improvement in conditions and possibilities regarding crossings of the border and onward travel into the country. Of key significance to the introduction of the new facilitations are changes of the border regime and an easing of the regulations concerning arrivals that have been achieved by action at central level.

Since 2015 in particular, it has been possible to note an unprecedented new scale and rate of change where the border regime is concerned. By virtue of Decisions of the President of the Republic of Belarus, a number of signed Decrees have appeared to bring zones of visa-free travel into existence, with a view to it being easier for visitors to cross over the state border into the country. Presidential Decrees have in fact both established visa-free zones and brought in other regulations making it easier for foreigners to visit. While on the one hand these changes are analogous to those found in other parts of the world at various different times, they on the other hand have certain unique features, especially given the specific nature of Belarus's isolation in the international arena over more recent decades. Thus, the last few years have seen three types of visa-free zone system come into existence, i.e.:

- border zones - on the Poland-Belarus border, and partly also that between Belarus and Lithuania;

- zones at airports - especially the capital-city (national) airport known as Minsk-2, but also the airports (and the railway stations) in Brest and Hrodna;

- visa-free regimes associated with special occasions, notably sporting events.

In terms of main reasons for establishment, the zones that have appeared are:

- along the western border (with a view to tourism developing in the Brest and Hrodna regions);

- by airports (for the sake of the development of the airports as such, but also the adjacent industrial and capital-city areas, as well as the furthering of regional tourism);

- linked closely with sporting events (to help ensure that the image of the country as a whole is promoted).

The entry into force of the Decrees in question, and the subsequent taking effect of visa-free regimes at all border crossings, has done much to increase the intensity of the traffic involving Polish people. Since 2015, there has been a steady rise in both absolute numbers of Poles travelling into Belarus, and the share of all visits they account for. This can be closely associated with the commencement of the visa-free regimes. Consecutive years after the years of introduction did not necessarily bring major further increases in numbers travelling; or even witnessed certain decreases. There is also a marked seasonality to numbers of Poles travelling to Belarus, with the peak obviously tending to coincide with the summer months. 